\title{
Pre-service Science Teachers' Informal Reasoning Patterns and Risk Perceptions in SSI: Case of Gene Therapy
}

\author{
Umran Betul Cebesoy ${ }^{1 *}$ \\ ${ }^{1}$ Department of Mathematics and Science Education, Usak University, Usak, TURKEY \\ * Corresponding author: umran.cebesoy@usak.edu.tr
}

Received: 25 Mar. $2021 \bullet$ Accepted: 17 Aug. 2021

Citation: Cebesoy, U. B. (2021). Pre-service Science Teachers' Informal Reasoning Patterns and Risk Perceptions in SSI: Case of Gene Therapy. European Journal of Science and Mathematics Education, 9(4), 211-229. https://doi.org/10.30935/scimath/11237

\begin{abstract}
:
One crucial characteristic of scientifically literate individuals is making informed decisions in socioscientific issues (SSI). Participants' reasoning patterns and their risk perceptions shape their decisions. Thus, determining participants' informal reasoning patterns along with their risk perceptions while making decisions in SSI becomes important. This study fulfills this important point by exploring pre-service science teachers' informal reasoning patterns and their risk perceptions in an SSI topic, specifically gene therapy. Eleven pre-service science teachers enrolling in two different public universities participated in the study voluntarily. The study was designed as a basic qualitative approach. The data were collected by semi-structured interviews focusing on the use of gene therapy in Huntington's disease and human intelligence cases. The results revealed that pre-service science teachers made decisions by using one (rationalistic, emotive, or intuitive) or more informal reasoning patterns together. Moreover, their risk perceptions were found to be based on the potential and severity of effects on humanity and society, participants' morals and values, side effects, and a general concern born out of fear. In addition to their risk perceptions regarding gene therapy, they referred to positive aspects of technology, negative aspects of technology, and a two-edged sword implying positive and negative aspects of technology as a whole while making decisions. These results altogether pin the importance of including multiple forms of informal reasoning and risk perceptions in the pre-service science teacher education programs.

Keywords: decision-making, genetics, gene therapy, pre-service science teachers, Socio-Scientific Issues (SSI), risk perception
\end{abstract}

\section{INTRODUCTION}

The promotion of scientific literacy has been documented in numerous reports (National Academies of Sciences, Engineering, and Medicine, 2016; National Research Council, 1996; Organisation for Economic Co-operation and Development [OECD], 2012). As a result, enhancing scientific literacy has been referred to as one of the crucial objectives of science education (Bossér et al., 2015; Dillon, 2009). To increase the number of scientifically literate individuals in society, students should engage in the discussion and decision-making process of complex, societally relevant issues by considering scientific knowledge, reasoning competencies, and multiple perspectives (Zangouri et al., 2018). Thus, socioscientific issues (SSI, hereafter) are considered to be fundamental for enhancing scientific literacy as they provide means for making informed decisions (Herman, 2018; Lederman et al., 2014; Sadler, 2004; Sadler \& Donnelly, 2006; Zeidler \& Keefer, 2003; Zeidler et al., 2002). Moreover, the individuals in SSI has been defined as open-ended issues that are controversial in nature requiring multiple perspectives during negotiating and resolving these issues (Sadler, 2004; Sadler \& Zeidler, 2004, 2005). With the increasing impact of technology, society is facing the challenges that arise from health and environment-related controversies (Gardner \& Jones, 2011; Kolstø, 2006; Lee \& Lee, 2015; Sadler \& 
Zeidler, 2005). Such issues are genetically modified organisms, stem cell research, cloning, nuclear power plantation, and pharmacogenomics (Gardner \& Jones, 2011; Lederman et al. 2014; Lee et al., 2012; Sadler \& Donnely, 2006; Sadler \& Zeidler, 2005). These issues require consideration of multiple perspectives including ethical, legal, social, economic, cultural, and political dimensions (Chang Rundgren \& Rundgren, 2010; Fang et al., 2019; Kahn \& Zeidler, 2017; Kirby, 2021; Kolstø et al. 2006; Owens et al., 2019). As dealing with SSI requires considering multiple perspectives, making decisions solely based on scientific claims is not possible (Eggert et al., 2013). Scientific knowledge provides context to understand the issues being discussed, but it provides partial context to include multiple perspectives (Owens et al. 2019). While scientific knowledge is a requirement while dealing with SSI, students need to incorporate scientific understanding with multiple perspectives (Kirby, 2021). Thus, making informed decisions by considering multiple perspectives and the complexity of SSI becomes crucial (Fang et al. 2019; Gardner \& Jones, 2011; Zeidler et al., 2002).

The open-ended, controversial and ill-structured nature of SSI create an appropriate context for making informed decisions (Fowler \& Zeidler, 2016). While making decisions, risk perceptions were found to have a crucial role (Kolstø, 2006; Sadler \& Zeidler, 2004b). Risk perceptions of individuals can be defined as how individuals interpret and describe an event that they consider risky (Gardner \& Jones, 2011). Exploring science instructors' risk perceptions about biotechnology, Gardner and Jones (2011) revealed that participants' risk perceptions were influenced by three factors: a) the potential frequency and severity of effects to the environment, human health, and society, b) uncertainty associated with the technology, and c) their own morals and values (p. 729). On the other hand, Christensen (2009) criticized that risk is an under-represented topic in science education and indicated that inclusion of risk during the discussion of science, technology, and society-related issues can be beneficial. Indeed, dealing with SSI can also develop participants' risk perceptions by considering the likelihood, impact, and valueladen ethical considerations (Christensen, 2009; Levinson et al., 2011; Rattcliffe \& Grace, 2003). Moreover, weighting risks while dealing with SSI is assumed to be a central component of decisionmaking (Rattcliffe \& Grace, 2003). Indeed, Es and Yenilmez-Ozturk (2021) revealed that teachers prioritized risk factors while making-decision in SSI. This was pointed out by Hancock and colleagues as the risks associated with SSI influence teachers' issue selection while SSI teaching (Hancock et al., 2019). Thus, the risk perceptions of participants need more attention in SSI research. Therefore, in this study, pre-service science teachers' risk perceptions along with their informal reasoning patterns while decision-making is explored.

Another important aspect of making decisions in SSI is reasoning patterns. Participants use a wide range of reasoning patterns (justifications) during making decisions in SSI topics. For instance, Wu and Tsai (2007) revealed that participants use social-, ecological-, economic-, and science/technology-oriented arguments while making decisions. In another study, Sadler and Zeidler (2005) revealed that college students used three types of informal reasoning as rationalistic, emotive, and intuitive. The results revealed that participants used all three types of reasoning patterns together. The participants in their study used rationalistic justifications such as health improvement, parents' rights, or disrupting the natural order. In some scenarios, the suffering of families or patients was more apparent which was resulted in sympathy towards the characters. Lastly, sometimes, participants made decisions by their instant feelings without providing sounding justifications. Similar informal reasoning patterns were revealed with pre-service science teachers (Topcu et al., 2011), with elementary school students (Ozden, 2020), and with high school students (Georgiou et al., 2020; Pope et al., 2017). In addition, factors such as religious beliefs were reported to influence participants' informal reasoning (i.e., Pope et al. 2017; Sadler \& Zeidler, 2005). For instance, Pope et al.'s (2017) study revealed that participants with a higher degree of religious beliefs tended to use more intuitive reasoning patterns while making decisions in biotechnology-related SSI. In addition to religious beliefs, other factors including science, ethics, and morality were found to influence participants' decisions and informal reasoning (i.e., Evren Yapicioglu \& Aycan, 2018; Karisan \& Cebesoy, 2021). In a recent study, Karisan and Cebesoy (2021) revealed that pre-service science teachers' decisions in various SSI topics were influenced by a wide range of factors 
including science, ethics/morality, economy, policy, and sociology/culture. However, Es and Varol (2019) indicated that undergraduate students were unable to consider the multidimensional structure of SSI while making decisions in SSI and lacked informal reasoning skills. These results resonate with the need for SSI-based instruction to consider multiple perspectives and develop informal reasoning patterns. Indeed, Georgiou et al.'s (2020) study revealed that SSI-based instruction helped students to develop more rationalistic informal reasoning patterns supported by scientific evidence and multiple perspectives (Georgiou et al., 2020).

Making informed decisions regarding SSI is assumed to be context-dependent (Colucci- Gray et al., 2006; Oulton et al., 2004; Sadler, 2004). Genetics-related SSI (genetically modified organisms, genetic engineering issues, cloning) is one of the important topics that can be used to enhance students' decision-making skills and promote scientific literacy (Lederman et al. 2014). Genetic manipulation, on the other hand, includes social, scientific, and ethical aspects that make the application of such technologies questionable (Lederman et al. 2014). Moreover, genetics-related SSI constitutes an authentic context for developing the decision-making skills of students. Lee (2007) argued that the social issues which have direct relevance to individuals' daily lives create an authentic context for dealing with SSI. As a result, many studies used genetics related SSI (cloning, human gene therapy, genetic testing) as context to explore participants' decision-making skills and informal reasoning patterns (Cebesoy, 2014; Črne-Hladnik et al., 2012; Pope et al. 2017; Sadler, 2004; Sadler \& Zeidler, 2004a, 2004b 2005; Simonneaux \& Chouchane, 2011; Topcu et al., 2011; van der Zande et al., 2011). As a common finding, the results revealed that participants' decisions were influenced by multiple factors and they used rationalistic, emotive, and intuitive reasoning patterns together. While most of these studies explored participants' decisions in multiple issues including gene therapy (i.e., Pope et al., 2017; Sadler \& Zeidler, 2004), Simonneaux and Chouchane's (2011) study differs as it solely focused on authentic gene therapy cases. They investigated college students' reasoning on the feasibility and acceptability of gene therapy. The results revealed that most of the participants favored gene therapies without a proper understanding of the uncertainties and risks associated with gene therapy. Gene therapy was chosen as context to explore pre-service science teachers' informal reasoning patterns and their risk perceptions for several reasons: First, it includes social, scientific, and ethical concerns as pointed out by Lederman et al. (2014). Second, gene therapy is one of the SSI that is highly debatable due to its content and risks associated with the procedure (Sadler \& Zeidler, 2004b). Third, it could be used to discuss different stakeholders' viewpoints (stop all gene therapy, proceed all gene therapy, use somatic (not being inherited to future generations) but not germ-line (being inherited to future generations), and proceed with caution). By considering one of the stakeholders' viewpoints, students would have a chance to explore a variety of different positions and multiple perspectives on gene therapy. Consequently, gene therapy was chosen as a context for this study to explore pre-service science teachers' informal reasoning patterns and their risk perceptions.

As developing students' informed decision-making skills is subject to numerous studies (i.e. Dawson \& Carson, 2020; Eggert et al., 2013; Gresh et al., 2017; Jho et al., 2014; Kolstø, 2006; Lee, 2007; Wu \& Tsai, 2011; Zohar \& Nemet, 2002), one crucial question still left unanswered: Are the teachers prepared for teaching SSI by considering its complex and multi-dimensional structure? The crucial question asked above is more evident when it comes to pre-service science teachers who are considered novice teachers and are reported to have more difficulty in implementing SSI when compared to their experienced peers (Cotton, 2006; Lee \& Witz, 2009). Existing literature reported that both science teachers and pre-service science teachers believe in the importance of teaching SSI in their classrooms (Sadler et al., 2006; Kara, 2072; Tidemand \& Nielsen, 2017). However, teachers are often reported as ill-equipped to address SSI in their classes (Chen \& Xiao, 2021; Owens et al. 2019). The literature highlights many factors which prevent effective implementation of SSI including lack of knowledge and teaching skills, reasoning competencies, confidence, and time (Byrce \& Gray, 2004; Carson \& Dawson, 2016; Genel \& Topcu, 2016; Hancock et al. 2019; Herman et al., 2017; Hofstein et al., 2011; Kara, 2012; Lee \& Yang, 2019; Liu \& Roehrig, 2019). In addition, curriculum alignment is another important factor that hinders effective SSI- 
based instruction (Lee \& Witz, 2009; Lee \& Yang, 2019). For instance, teachers tended to teach SSI if the topic is aligned with the curriculum (Lee \& Yang, 2019). Chen and Xiao (2021) pointed out professional development of teachers is a necessity for effective SSI-based instruction. While professional development for teachers is achieved throughout effective professional development programs (e.g., Dawson \& Carson, 2020; Hancock et al., 2019) the same professional development for SSI-based instruction is possible with effective undergraduate courses pre-service teachers. However, Hofstein et al. (2011) indicated that undergraduate courses provided limited opportunities for pre-service teachers to develop effective teaching skills.

\section{Purpose of the Study}

Students' decision-making skills in SSI can be enhanced through explicit training in decision-making (Eggert et al., 2013; Gresch et al., 2017). If teachers aim to develop students' decision-making skills, they themselves should possess the required skills and competencies for effective implementation of SSI in their classes (Herman et al., 2018; Owens et al. 2019). Teacher professional development is the key element to promote teachers' engagement in SSI teaching (Owens et al., 2021). Here, the teacher education programs which train qualified teachers come to the fore. Concerning Turkey, however, the science teacher education programs which are centralized and regulated by the Higher Education Council of Turkey do not provide compulsory courses about teaching SSI (HEC, 2007). On the other hand, the primary science curriculum aims to raise future generations as qualified decision-makers in SSI by considering multiple viewpoints (Ministry of National Education [MoNE], 2018). This creates a crucial question to be answered: How can teachers raise future generations equipped with informed decision-making skills without having proper instruction through their undergraduate education? This study seeks the answer to this question by investigating how pre-service teachers make decisions in an SSI topic which can provide valuable clues about the necessity of including SSI-based teaching in preservice teacher education programs. Based on this purpose, three research questions were examined:

1. How do pre-service science teachers make decisions in the gene therapy scenario?

2. What are the informal reasoning patterns that pre-service science teachers exhibit while making decisions?

3. How do the pre-service science teachers perceive the risk factors associated with the gene therapy scenario?

This study is unique in several ways: First of all, to our best knowledge, there is limited study that solely focused on gene therapy. Previous studies mainly focused on multiple scenarios on genetic engineering issues such as cloning, gene therapy, and fetal tissue transplantation (e.g., Bell \& Lederman, 2003; Cebesoy, 2014, 2020; Sadler \& Zeidler, 2004a). Simonneaux and Chouchane's (2011) study differs from existing studies as the researchers explored college students' reasoning on the feasibility and acceptability of gene therapy by using authentic gene therapy cases. As weighting risks while making decisions in SSI is crucially important (Rattcliffe \& Grace, 2003), we argue that risk perceptions also need to be taken into account while investigating participants' decisions and informal reasoning patterns. Second, for raising students as informed decision-makers as highlighted in the Turkish primary science curriculum (MoNE, 2018), science teachers and future science teachers need to be aware of SSI and their own decision-making process while dealing with SSI. Thus, this study seeks how future science teachers make decisions while dealing with SSI. By unveiling their informal reasoning patterns and risk perceptions while making decisions, future courses focusing on SSI-based instruction could be designed and planned. 


\section{METHOD}

\section{Research Design}

The basic (generic) qualitative approach was used in this study. The studies designed by using the basic qualitative approach are not guided by a series of assumptions used in other types of qualitative approaches such as ethnography, phenomenology, or grounded theory (Caelli et al., 2003). As the present study aimed to explore how pre-service science teachers made decisions in an SSI topic, namely gene therapy, and to explore their justifications and their perceptions of risk factors, a basic qualitative approach was preferred.

\section{Participants}

Eleven third-year (junior) pre-service science teachers enrolled at two public universities located in central Anatolia and western Anatolia regions of Turkey voluntarily participated in the study. In this study, the participants were selected purposefully. Here, the selection of 'information-rich cases' as Patton (1990) identified enabled the researcher to investigate the purpose of the research in-depth. Snowball sampling is one of the most common types of purposeful sampling in qualitative research (Merriam, 1998). In the snowball sampling approach, the researcher reaches new participants through the contact information provided by other participants (Noy, 2008). The researcher reached the first three participants who enrolled in an elective course offered in the third year of the science teacher education program. The main reason for choosing third-year pre-service science teachers as participants of the study was that third-grade pre-service science teachers completed compulsory biology courses and were enrolled in genetics and biotechnology course at the time of the study. Then, these participants referred to other participants who might want to join the study. The researcher accessed those new participants and invited them to join the study. Eventually, the researcher reached a total of 11 female third-grade pre-service science teachers who voluntarily accepted to participate in the study. The teacher education system is centralized and regulated by Higher Education Council [Yüksek Öğretim Kurumu-YÖK] in Turkey. Thus, all the pre-service science teachers participating in the study followed the same curriculum offered in science teacher education programs. In Turkey, science teacher education programs last eight semesters (4 years). Pre-service science teachers complete a series of compulsory and elective courses including Physics, Chemistry, Biology, Mathematics along with pedagogical courses (e.g., Introduction to Education, Educational Psychology; Measurement and Assessment), pedagogical content courses (e.g., science teaching methods), and teaching practices (Higher Education Council, 2007).

\section{Data Collection}

Data can be collected through semi- or full-structured interviews in the basic qualitative approach (Percy et al., 2015). In this study, data were collected by using semi-structured interviews where the questions are formed less structured and more flexible as Merriam (1998) indicated. The interview questions focused on a genetics-related SSI, gene therapy. The researcher specifically chose the topic for three reasons: First, genetic engineering issues like gene therapy of genetically modified foods include social, scientific, and ethical issues arising from the nature of genetic manipulation. Thus, it provides an opportunity to promote scientific literacy (Lederman et al. 2014). Second, the primary science curriculum highlighted the importance of developing students' decision-making, scientific thinking, and informal reasoning skills by using SSI (MoNE, 2018, p. 9). Last, more specifically the 8th-grade science curriculum focused on the development of students' decision-making and argumentation skills in dilemmas arising from biotechnology applications and discuss future genetic engineering and biotechnology applications (MoNE, 2018, p. 49). Furthermore, the gene therapy scenario used in this study is used in previous studies conducted with science teachers (Cebesoy, 2014) and more recently, with pre-service science teachers in an intervention study (Karisan \& Cebesoy, 2021). 
The semi-structured interviews with participants were conducted in a private office and the interviews were audio-typed after informing the participants. Each interview began with the distribution of the scenario to the participant and a brief description of the study and the scenario itself. Then, the researcher asked a series of questions in the scenario. The interviews lasted for 20-30 minutes. The scenario is briefly explained below:

\section{Use of Gene Therapy on Huntington's Disease and Intelligence}

We followed the interview protocol designed by Sadler and Zeidler (2004). The interview protocol and the scenario used in the protocol were developed by Sadler and Zeiler (2004) and used in previous studies (Cebesoy, 2014; Karisan \& Cebesoy, 2021; Sadler \& Zeidler, 2004, 2005; Topcu et al. 2011). The protocol consisted of a few steps: First, the researcher explained the purpose of the interview and asked their permission to audiotape the interview. Then a handout explaining the mechanism underlying gene therapy was introduced along with the scenarios. In the scenarios, first, how gene therapy is used for the treatment of Huntington's disease was explained. Then, it was mentioned that gene therapy can also be used to increase the intelligence of human offspring. After reading the handout, the participants were asked a series of questions forming around if the gene therapy should be used for the treatment of Huntington's disease. Following this, the scenario continued with the discussion of the use of gene therapy for increasing human intelligence. The questions were designed to explore participants' informal reasoning patterns and risk perceptions (Please see Appendix A for scenarios used in the study and Appendix B for sample questions asked in the interview protocol). The scenario was translated and adapted into Turkish by the researcher (Cebesoy, 2014). The equivalence of Turkish and English versions was checked by experts in science and biology education and language experts of the university. While language experts of the university checked the equivalency of Turkish and English versions, two experts in science and biology education checked its appropriateness for the study. Also, pilot interviews with science teachers were conducted to check the understandability and sufficiency of given information for answering the questions in the scenario.

\section{Data Analysis}

The data collected from the semi-structured interviews were transcribed verbatim. The thematic analysis offers a systematic way of identifying, organizing the data, and providing insight into the data through themes (Braun \& Clarke, 2012). Here, the researcher follows the six steps as getting to know the data, generating initial codes, searching for themes, reviewing the themes, defining the themes, and writing the report. There are different approaches while conducting a thematic analysis. One of them is the deductive thematic analysis in which the theme and code development are based on existing concepts and ideas (Fereday \& Muir-Cohcrane, 2006). In this approach, a template of codes based on previous research has been used. In this study, the themes used for the informal reasoning patterns were based on Sadler and Zeidler's (2005) study. Sadler and Zeidler (2005) identified three forms of informal reasoning: (a) rationalistic, (b) emotive, and (c) intuitive informal reasoning. While making decisions in SSI, participants justified their reasons by using rationalistic standpoints based on health improvement, parental rights, or the betterment of society. Participants justifying their decisions with emotive informal reasoning patterns mainly showed empathy or sympathy towards the parents or child who is dealing with Huntington's disease. They were concerned about the pain and the suffering both the parents and the child with the disease would go through while explaining their reasons. Lastly, the pre-service science teachers who used intuitive informal reasoning showed a degree of immediate reactions to the questions without proper justification for their decisions. The following excerpts taken from the pre-service science teachers' interviews were presented in each form of informal reasoning:

I think it [referring to gene therapy] should be used. I am in the favor of the application of gene therapy. It is thought to be effective in some types of cancer as an alternative to cancer drugs. As I see hope for a cure, I think it should be used. (PT$3 /$ rationalistic informal reasoning) 
If there is such a study, I think it should be continued. Healthier generations would eventually be reproduced and this disease would no longer be carried over other children and passed on to other genes. Maybe this disease will disappear in this way. (PT-5/ rationalistic informal reasoning)

The excerpts above presented pre-service science teachers' reason-based justifications while making decisions. While PT-3 refers to the importance of health improvement as a justification for her decision, PT-5 refers to a disease-free society in the case of deleting the Huntington's disease gene from the existing genes. It suggests betterment of society which is a consequence-based reasoning pattern (Sadler \& Zeidler, 2004).

While making-decision, I mostly thought of parents. They are taking responsibility while deciding to give birth to a new life. I think they would suffer a lot if their children had Huntington's disease. (PT-1/emotive informal reasoning)

If I were that child, I would want my parents to do it [referring to gene therapy] before I was born. Living even in 35 years is just giving me hope. (PT-10/ emotive informal reasoning)

These specific quotations include participants' empathy or sympathy towards the parents and the sick child in the scenario by expressing the suffering or putting themselves in that character's shoes. As a result, these quotations represent participants' emotive informal reasoning patterns.

Definitely not! [using gene therapy on human intelligence should not be allowed] (PT-8/intuitive informal reasoning)

I think it is just not ethical to use gene therapy for intelligence. (PT-7/intuitive informal reasoning)

Lastly, not very frequently, but sometimes pre-service science teachers showed immediate reactions without proper justifications which were represented with the above-stated quotations.

To explore participants' risk perceptions, we benefit from Gardner and Jones' (2011) classification of risk perceptions as the potential and severity of effects to humanity and society, participants' morals and values, and a general concern born out of fear. In addition to this classification, we also revealed another theme as the side effect from participants' responses which was referred to in the literature (Lee \& Lee, 2015; van der Zande et al., 2011).

For ensuring the anonymity of the pre-service teachers, an ID number (from 1 to 11 ) is given to each participant. PT-1 represents the first participant in the study. Square brackets ([]) were used to complete the meaning by the researcher.

\section{The Trustworthiness of the Study}

The trustworthiness of the study can be ensured by using different strategies. To ensure credibility and confirmability (equivalent to internal validity in quantitative research), peer examination (investigator triangulation) was used (Archibald, 2016; Guion, 2002; Merriam, 1998). After transcribing the interview data verbatim, the researcher coded the data based on the framework of Sadler and Zeidler's (2005) study of informal reasoning for the second research question. The researcher used another framework for analyzing risk perceptions extracted from existing risk perception literature (Garder \& Jones, 2011, Lee \& Lee, 2015; van der Zande et al. 2011). Then another expert in SSI, specifically reflective judgment, was invited to the study as the second coder to confirm the appropriateness of informal reasoning and risk perception frameworks determined by the researcher. She coded independently $20 \%$ of the data and two researchers gathered to discuss the frameworks. For ensuring a consensus on the analysis frameworks inter-coder reliability based on percent agreement was used by dividing the total number 
Table 1. Pre-service science teachers' decision-making

\begin{tabular}{lllll}
\hline Participant & $\begin{array}{l}\text { Gene therapy for Huntington's } \\
\text { Disease }\end{array}$ & Informal reasoning pattern & $\begin{array}{l}\text { Gene therapy for } \\
\text { intelligence }\end{array}$ & $\begin{array}{l}\text { Informal reasoning } \\
\text { pattern }\end{array}$ \\
\hline PT-1 & Approve & Rationalistic-Emotive-Intuitive & Disapprove & Rationalistic \\
PT-2 & Approve & Rationalistic & Disapprove & Rationalistic-Emotive \\
PT-3 & Approve & Intuitive-Rationalistic & Disapprove & Rationalistic-Emotive \\
PT-4 & Approve & Intuitive-Rationalistic & Disapprove & Intuitive- Rationalistic \\
PT-5 & Approve & Rationalistic-Emotive & Approve & Rationalistic \\
PT-6 & Approve & Rationalistic & Disapprove & Rationalistic \\
PT-7 & Approve & Rationalistic-Emotive & Disapprove & Intuitive-Rationalistic \\
PT-8 & Approve & Rationalistic-Emotive & Disapprove & Intuitive-Rationalistic \\
PT-9 & Disapprove & Rationalistic & Disapprove & Intuitive-Rationalistic \\
PT-10 & Disapprove & Intuitive-Emotive & Disapprove & Intuitive-Emotive \\
PT-11 & Approve & Rationalistic-Emotive & Disapprove & Intuitive-Emotive \\
\hline
\end{tabular}

of agreements of both researchers into the total number of agreements and disagreements (Lombard et al., 2002; Miles \& Huberman, 1994). The values for informal reasoning patterns and risk perceptions were found to be $79 \%$ and $82 \%$ respectively showing that the coding was compatible. Then the researcher continued to analyze the rest of the data based on the frameworks. Another way of ensuring trustworthiness was member checking (Merriam, 1998). The researcher took back verbatim data and initial coding to four participants to provide means to participants to endorse their informal reasoning patterns and their risk perceptions. Lastly, an audit trail (Merriam, 1998) was adopted. The researcher explained data collection and theme categorization procedures in detail in previous sections as Merriam (1998) indicated.

\section{RESULTS AND DISCUSSION}

The present study explored pre-service science teachers' decision-making in an SSI topic, specifically gene therapy. First, pre-service science teachers' decision-making and how their reasoning changes were explored. Then, how pre-service science teachers perceive the risk factors were examined in detail.

When Table 1 was examined, it could be seen that the participants' decisions changed even in the same genetic application (gene therapy) when the context differed. While most of the participants approved the use of gene therapy for Huntington's Disease, the same participants were found to be against using gene therapy for increasing human intelligence. According to Table 1, the participants usually approved the use of gene therapy for Huntington's disease while only two participants (PT-9 and PT10) disapproved. Concerning the use of gene therapy for intelligence, all pre-service science teachers except one (PT-5) disapproved of the idea of using gene therapy for increasing intelligence. After examining their decisions, we also explored how they justify their decisions by exploring their informal reasoning patterns. As seen from Table 1, pre-service science teachers used a variety of informal reasoning patterns at the same time while making decisions showing the complexity of the decisionmaking process. While teacher candidates sometimes used informal reasoning patterns alone (only emotive or rationalistic informal reasoning), they frequently displayed multiple reasoning patterns while making decisions in gene therapy scenarios. Table 2 shows these single and multiple reasoning patterns by providing excerpts.

As seen in Table 2, the pre-service science teachers usually adopted multiple informal reasoning patterns while making decisions in gene therapy scenarios. For instance, one participant (PT-7) showed empathy by expressing she put herself in the parents' shoes and expressed that the disease (Huntington's Disease) is terrible while also showing rationalistic concerns including health improvement and parental responsibilities at the same time. Sometimes, participants used three informal reasoning patterns (intuitive, rationalistic, and emotive informal reasoning) at the same time (i.e., PT-1). Intuitive informal reasoning showing participants' immediate reactions towards scenarios always was stated first by the pre-service science teachers. When the interviewer asked to explain their reasons, they explained by using rationalistic concerns (i.e., letting gene therapy be used can lead to its 
Table 2. Participants' combined informal reasoning patterns

\begin{tabular}{|c|c|c|c|}
\hline Decision & Participant & $\begin{array}{l}\text { Informal reasoning } \\
\text { pattern-Scenario }\end{array}$ & Excerpt* \\
\hline \multirow[t]{5}{*}{ Approve } & PT-2 & $\begin{array}{l}\text { Rationalistic- } \\
\text { Huntington's Disease }\end{array}$ & $\begin{array}{l}\text { 'I think it [gene therapy for Huntington's Disease] should be used. If there is } \\
\text { such treatment that will demolish those disease cells, the child will be less } \\
\text { likely to get sick. I believe this kind of treatment should be developed.' }\end{array}$ \\
\hline & PT-5 & $\begin{array}{l}\text { Rationalistic- } \\
\text { Intelligence }\end{array}$ & $\begin{array}{l}\text { 'I said Yes for previous case [referring the gene therapy Huntington's } \\
\text { Disease]. Concerning intelligence, in this case, there will be more artists and } \\
\text { scientists. Eventually, the country will change so does the world. I think } \\
\text { gene therapy could be used on intelligence, too. It is a good thing that people } \\
\text { become smarter and the country thrives.' }\end{array}$ \\
\hline & PT-7 & $\begin{array}{l}\text { Rationalistic } \\
\text { Emotive- Huntington's } \\
\text { Disease }\end{array}$ & $\begin{array}{l}\text { 'If the treatment works and is applied successfully, it should definitely be } \\
\text { used. It is for health improvement. It is better to do this [gene therapy for } \\
\text { Huntington's Disease] rather than going through that terrible disease. } \\
\text { Frankly, I thought of myself as a parent. It is the parents' responsibility to } \\
\text { decide this.' }\end{array}$ \\
\hline & PT-4 & $\begin{array}{l}\text { Intuitive } \\
\text { Rationalistic- } \\
\text { Huntington's Disease }\end{array}$ & $\begin{array}{l}\text { 'It could be used. Why not? } \\
\text { I: Why do you think so? } \\
\text { If the aim was demolishing that disease, then, why not? If not prevented, } \\
\text { the disease [referring to Huntington's Disease] will spread further. } \\
\text { Therefore, this disease should be treated by demolishing the disease genes.' }\end{array}$ \\
\hline & PT-1 & $\begin{array}{l}\text { Intuitive } \\
\text { Rationalistic Emotive - } \\
\text { Huntington's Disease }\end{array}$ & $\begin{array}{l}\text { 'Yes, it could be used.' } \\
\text { I: Why do you think so? } \\
\text { 'If the location of this gene [referring to the gene causing Huntington's } \\
\text { Disease] is determined, then, why not use it? This would be a good thing for } \\
\text { people. There will be no disease. Here, the demolishing of the disease is } \\
\text { important. I mainly thought of parents. They would suffer a lot along with } \\
\text { their child.' }\end{array}$ \\
\hline \multirow[t]{5}{*}{ Disapprove } & PT-9 & $\begin{array}{l}\text { Rationalistic - } \\
\text { Huntington's Disease }\end{array}$ & $\begin{array}{l}\text { 'It should definitely not be used. If this treatment method was developed } \\
\text { and the disease was demolished and no other disease occurred afterward, } \\
\text { the human race would definitely change other normal genes because they } \\
\text { are greedy.' }\end{array}$ \\
\hline & P-6 & $\begin{array}{l}\text { Rationalistic - } \\
\text { Intelligence }\end{array}$ & $\begin{array}{l}\text { 'I think it should not be used. There might be some situations where science } \\
\text { and technology would be used by wicked people like atomic bombs. This } \\
\text { [referring to using gene therapy for intelligence] could be used similarly. It } \\
\text { is far too dangerous.' }\end{array}$ \\
\hline & PT-3 & $\begin{array}{l}\text { Rationalistic } \\
\text { Emotive-Intelligence }\end{array}$ & $\begin{array}{l}\text { 'Intelligence does not mean anything to me. The treatment of diseases or } \\
\text { hunger is more important. I think it has no benefits for us, as a society, to be } \\
\text { smarter. I think we need to be equal as soon as possible. It would be unfair for } \\
\text { children whose intelligence was not increased. I think it is unfair for all } \\
\text { people.' }\end{array}$ \\
\hline & PT-7 & $\begin{array}{l}\text { Intuitive } \\
\text { Rationalistic- } \\
\text { Intelligence }\end{array}$ & $\begin{array}{l}\text { 'I think it is just not ethical to use gene therapy for intelligence.' } \\
\text { I: Why do you think so? } \\
\text { "We cannot control it. If some people in one country found it [referring to } \\
\text { the gene for intelligence], then, they would use it only for their citizens. } \\
\text { There would be classes that could access gene therapy and those who could } \\
\text { not in society. It is definitely open to using in other fields.' }\end{array}$ \\
\hline & PT-10 & $\begin{array}{l}\text { Intuitive } \\
\text { Emotive- Intelligence }\end{array}$ & $\begin{array}{l}\text { 'Never! It is never acceptable. It is not ethical either' } \\
\text { I: Why do you think so? } \\
\text { What would happen if everybody was smarter than ever? I do not think it is } \\
\text { suitable at all. Intelligence can be increased by effort. It is difficult for that } \\
\text { child [referring to the child whose intelligence is increased by gene therapy } \\
\text { application], too. Parents would not offer any choice other than being } \\
\text { successful in their children. It is just not right. }\end{array}$ \\
\hline
\end{tabular}

*Note: Bold sentences show evidence of rationalistic moral reasoning.

The underlined sentences show evidence of emotive moral reasoning.

The italicized sentences show evidence of intuitive moral reasoning. 
use in other unacceptable contexts, health-related reasons, the segregation in the society) and/or emotive concerns (i.e., empathy towards the characters, ethics, rights or equality). Some pre-service science teachers (PT-2 and PT-5) displayed only rationalistic informal reasoning patterns in both Huntington's Disease and intelligence scenarios indicating participants' reliance on a single perspective while making a decision.

\section{Analysis of Pre-service Science Teachers' Perceived Risk Associated with the Gene Therapy Scenario}

The third research question focused on the pre-service science teachers' perceptions about the risk factors associated with gene therapy. While making decisions in SSI, evaluating the pros and cons of scientific and technological developments is often a prerequisite (Fang et al. 2019; Pedretti, 1999). Besides, there are other factors reported that can be influential on decision-making on SSI including uncertainty (Christensen, 2009; Colucci-Gray et al., 2006; Garner \& Jones, 2011a; Kolstø, 2006; Lee \& Lee, 2015; van der Zande et al., 2011), risk factors (Christensen, 2009; Gardner \& Jones, 2011a, 2011b; Levinson et al., 2011), side effects (Lee \& Lee, 2015; van der Zande et al., 2011), pros and cons (Acar et al., 2010; Fang et al., 2019; Kolstø, 2006; Pedretti, 1999) and skepticism (Fang et al., 2019; Sadler et al., 2007; Simonneaux \& Chouchane, 2011). We classified their perceptions of risk under four themes: (a) the potential and severity of effects to humanity and society, (b) side effects of gene therapy, (c) their morals and values, (d) a general concern born out of fear.

When the pre-service science teachers' concerns were explored, almost all participants expressed the potential effects of gene therapy and how it would severely affect humanity and society. Sample excerpts expressing these concerns are presented below:

I am concerned about the misuse of gene therapy. It worries me that everyone could want to de gene therapy for their own good. People living in Turkey might not have access to it while their counterparts in the USA will easily access it. It is kind of pulling strings for someone else. (PT-7)

Human beings have a weakness. If people use gene therapy for their weakness, this constitutes serious problems. While some are suffering, some will use gene therapy for other purposes. For instance, for intelligence or beauty. I'm worried about the misuse of gene therapy. (PT-6)

I am concerned about segregation. The ones that can have access to gene therapy and those who cannot. Society would be divided into two. I am concerned about the social segregation that gene therapy would create. (PT-1)

The above excerpts present concerns of pre-service teachers about the misuse of gene therapy such as using it for other purposes (e.g., for intelligence or beauty reasons), use in the interest of countries, or segregation in the society. Another theme we revealed was participants' concerns regarding the side effects of gene therapy. Some pre-service science teachers were concerned that there might be side effects as the gene therapy application is an intervention to the genes whose functions are not fully known well.

I am concerned about new diseases that might arise after the intervention of genes. (PT-10)

I am worried that my knowledge about gene therapy might be limited. Would this gene therapy will affect his/her [referring to the person whose genes are altered] own children? Are these genes inherited? Are there any side effects? They are all matter. (PT-4) 
Of course, I have concerns. When we are treating it, we alter them. It seems to me that we are harming while doing it. ...like genetically modified products. On one hand, we will produce a lot of products, but on the other hand, we will increase the number of diseases. There may be side effects like this. (PT-2)

While expressing their concerns, participants also indicated their concerns about how gene therapy applications can conflict with their moral beliefs and values. Exemplifying this concern, sample excerpts are provided below:

There could be some mistakes during gene therapy application. Tampering genes could create problems. There might be a problem during gene transfer. This is violating the rights of the unborn child. (PT-5)

There are many things that we still do not know about gene therapy. For instance, I am concerned about its use on animals. I mean experimental studies on animals make me concerned. There should be some standards and regulations about its use.' (PT-3)

'I think, if a technologic application like this [referring to gene therapy] can constitute equality of opportunity, then, it is a good thing. Otherwise, it will create problems in society as a whole concerning inequality. (PT-9)

Above excerpts present examples of how participants' values or morality reflect their concerns. In these excerpts, child rights, experimental studies on animals, or equality of opportunity constitute a concern for the use of gene therapy. Another theme revealed in the present study is participants' general concerns born out of fear.

It [referring to gene therapy] just makes me concerned. This is why I am totally against its use in any circumstances. There is nothing guaranteed. Even if it was applied to the disease, everything might get worse. The developmental process in the embryo might be different. I am so afraid that it might turn into another disease. Thus, I would not definitely do it [referring to gene therapy]. (PT-9)

The trend is really scary for me. So now artificial babies would appear. In further levels, this [referring to gene therapy] would not be limited to the diseases. I think it would be applied to change the physical characteristics of the child such as intelligence and appearance. This is really scary. (PT-8)

These excerpts present participants' concerns born out of fear of whether it would create another disease or it would be applied in unacceptable contexts such as intelligence or physical appearance. The uncertainty in the gene therapy application created fear for these pre-service science teachers.

As gene therapy is related to technology, it was revealed that participants also had opinions about the technology itself. Their opinions can be categorized under three headings as positive aspects of technology, negative aspects of technology, and a two-edged sword implying positive and negative aspects of technology as a whole. The first group of participants believed that technology is a facilitator for our lives by helping to create innovations for our life. Moreover, they indicated that technology helps people to increase their knowledge about genes. Sample quotations representing this theme presented below:

Technology does not make me concerned. At least for now... it makes our lives easier. Our lives are getting easier step by step. (PT-4) 
Instead of getting concerned, I am happy about any technological innovation. Even talking about gene therapy makes me excited. If we think that such a thing [referring to gene therapy] will happen, there will be very rapid advances in technology. There will be more inventions and discoveries. That is, technological developments will positively affect developments in science. (PT-5)

I think the advancement of technology is a good thing for us. Technology is everywhere like in the food or health industry. If technology does not advance, we cannot do anything without it anymore. We are very used to it. (PT-9)

I think that the advancement of technology is a good thing. It helps to develop gene therapies and genetic technologies and helps us to increase our knowledge about genes. (PT-11)

Besides these quotations, some participants solely focused on negative aspects of technology such as using it for their own good, destroying nature and humanity, or malicious use. Sample quotations exemplifying this theme are presented as:

It just makes me concerned unless the control over technology belongs to us. However, we see that technology is destroying humanity in some films such as Jurassic Park... I think technology will destroy humanity at some point. (PT-8)

The advancement of technology makes me concerned a lot. We are consuming everything we have. Technology is destroying nature and polluting it. Even young children aged one or two are addicted to smartphones.' We are destroying ourselves by being addicted to technological applications. (PT-10)

I am concerned about technology. I am concerned about how each country would access information produced by technology. Atomic bombs, chemical pollution are all the results of technology. There could be an abuse of technology. All are very worrying. (PT-6)

Finally, some participants were both hopeful and doubtful of the technology. These participants' opinions were categorized under a two-edged sword theme. The two-edged sword theme reflects participants' pros and cons analysis of the technology. Sample excerpts are provided as:

With the advancement of technology, gene therapy is developing more. The two are bounded by each other. There are also negative aspects of the rapid development of technology. The communication between us is decreasing. People are totally addicted to the internet which makes them less emotional. (PT-2)

As technology advances, new treatment options for other diseases will be found. People do not have to struggle with diseases. A lot of disease-related genes will be destroyed which sounds good. With this respect advancement of technology makes me both hopeful and worried. While worrying about social segregation and the creation of different future generations, I am hopeful about decreasing the number of dreadful diseases. (PT-1)

\section{DISCUSSION}

This study explored (a) how pre-service science teachers make decisions in gene therapy scenario including two cases (Huntington's Disease and human intelligence), (b) informal reasoning patterns while they used during decision-making in a specific scenario, and (c) their perceptions of risk factors associated with gene therapy and advancement of technology. The results revealed that participants' decisions could change based on their informal reasoning patterns even in the same case. While 
participants generally approved the use of gene therapy for the treatment of Huntington's disease, they were against the use of gene therapy for increasing human intelligence showing the context-dependence of SSI. In line with this finding, existing studies also revealed that participants favored some genetics applications more as these applications make people healthier (Cebesoy, 2014; Karisan \& Cebesoy, 2021; Khishfe, 2012; Kolstø, 2006; Sadler \& Zeidler, 2004, 2005; Topcu et al., 2011). Health-related benefits of genetic applications, in fact, were reported as an influential factor that affected the participants' decision-making in SSI topics. Kolstø (2006) argued that as health is a natural part of life, it is crucial for making decisions. Indeed, in this study, pre-service science teachers approved the use of gene therapy for the health-related benefits that gene therapy provides for patients and their families. Still, there were some participants who were hesitant about the use of gene therapy. Actually, this finding contrasted with Simonneaux and Chouchane's (2011). While they found that college students enrolled in the biotechnology institute favored gene therapy without considering the uncertainties and risks associated with gene therapy. In contrast, pre-service teachers in this study acknowledged the uncertainties and risks associated with gene therapy as there were some participants who were totally against the use of gene therapy either in Huntington's disease or in intelligence and the others agreed on the use for Huntington's disease but disagreed on the use of human intelligence cases. While there can be cultural differences (one study was conducted in Tunisia, the other was conducted in Turkey) and departmental differences (one study was conducted with college students in biotechnology institute and the other was conducted with pre-service science teachers), the difference might be related with pre-service teachers' being more aware of gene therapy when compared to their counterparts in Tunisia. That is pre-service teachers in this study considered different stakeholder's viewpoints as proposed by Sadler and Zeidler (2004b) during the decision-making process.

We also explored how pre-service science teachers justified their decisions. The results revealed that even though some participants used a single reasoning pattern, they mainly made decisions based on considering multiple reasoning patterns. This finding echoes with the existing literature which reported participants' reliance on the use of multiple factors during decision-making in SSI topics (Cebesoy, 2014; Chang Rundgren \& Rundgren, 2010; Es \& Varol, 2019; Evren Yapicioglu \& Aycan, 2018; Karisan \& Cebesoy, 2021; Sadler \& Zeidler, 2004, 2005; Sadler, 2004; Topcu et al., 2011; Wu \& Tsai, 2007). Due to the complex nature of SSI including open-endedness, skepticism, and uncertainty (Colucci-Gray et al., 2006; Fang et al. 2019; Sadler \& Zeidler, 2004, 2005), adopting multiple perspectives in decision-making is an expected result. While making decisions in SSI topics, it is almost impossible to make simplistic decisions. As a result, morality and ethical issues are usually reported to be included and involved in SSI-based decision-making (Chang Rundgren \& Rundgren, 2010; Sadler, 2004; Zeidler \& Keefer, 2003). Confirming this, Sadler and Zeidler (2005) also reported that some participants tended to emphasize the moral and ethical implications of the issues in the scenarios presented to them. In addition, Karisan and Cebesoy (2021), and Cebesoy (2014) also reported that pre-service and in-service science teachers' decisions in genetics-related SSI were mainly influenced by ethics and morality. Even though adopting multiple perspectives and factors are desired in the decision-making process regarding SSI, there is evidence that shows participants' reliance on one single perspective (Es \& Varol, 2019; Liu et al., 2011; Topcu et al. 2011). For instance, Liu et al. (2011) reported that half of the college students (54.2\%) made decisions based only on a single disciplinary perspective while the other $36.2 \%$ integrated two disciplinary perspectives. Es and Varol's (2019) study revealed similar results: Undergraduate students were unable to consider the multidimensional structure of SSI while making decisions. In line with these findings, this study also revealed there were a few participants who used a single perspective while making decisions (e.g., rationalistic informal reasoning). This finding also shows there still is a need for increasing participants' use of multiple perspectives during decision-making on SSI. Actually, this finding is also important to answer our main question: Are the teachers prepared for teaching SSI by considering its complex and multi-dimensional structure? It could be difficult to teach the complex and multi-dimensional structure of SSI while teachers themselves do not consider these aspects while making decisions. Indeed, the literature highlights the importance of considering multiple perspectives 
for effective SSI-based instruction (Herman et al., 2018; Owens et al., 2019). This can be achieved through professional development programs specifically designed for developing reasoning competencies in SSI (e.g., Dawson \& Carson, 2020; Evren Yapicioglu \& Aycan, 2018; Hancock et al., 2019). Such programs can develop teachers' reasoning competencies and help them to consider multiple perspectives while teaching SSI in their classes.

Concerning different informal reasoning patterns, pre-service science teachers, in this study, either used a rationalistic reasoning pattern or combined it with emotive and intuitive reasoning patterns during decision-making in the gene therapy scenario. The participants deliberately relied on rationalistic consequences including health improvement or patient rights. This finding was consistent with Topcu et al.'s (2011) study which reported that pre-service science teachers mainly used rationalistic informal reasoning in gene therapy scenarios. Similarly, Sadler and Zeidler (2004) reported that rationalistic moral reasoning patterns were more evident when compared to emotive and intuitive moral reasoning in genetic-related SSI. Consistent with our finding, Pope et al.'s (2017) and Georgiou et al.'s (2020) studies also revealed similar results even conducted with high school students (aged 16-18 years). One possible reason for the more evident rationalistic informal reasoning pattern might be that participants being more knowledgeable about the issues being discussed. Supporting this assumption, Georgiou et al. (2020) revealed that participants who used rationalistic reasoning pattern supported their decisions with scientific data more and produced stronger arguments. However, Sadler and Donnelly's (2006) findings indicated the opposite. They did not reveal any evidence showing a relationship between argumentation quality and content knowledge. That is the participants who were knowledgeable about gene therapy and cloning did not necessarily produce stronger arguments. Another possible explanation for using the more rationalistic informal reasoning pattern might be that rationalistic informal reasoning patterns focused on rational inferences such as the consequences of gene therapy (health improvement or betterment of society) or principles (taking human life or parental rights). Participants might tend to use consequences or principles more when compared to care-based perspective (emotive informal reasoning) or instant reactions (intuitive informal reasoning).

Besides exploring pre-service science teachers' justifications, this study also revealed their perceptions of risk about gene therapy and the advancement of technology. Their concerns were focused on the potential and severity of effects to humanity, side effects, their own morals and values, and general concern born out of fear. Gardner and Jones (2011) found similar concerns as influential factors in participants' decisions towards biotechnology. In a similar study conducted by Gardner et al. (2010), students' perceptions of risk towards nanotechnology were found to be influenced by the effects of nanotechnology products on the health and wellbeing of individuals. This finding resonates with the first theme revealed in this study as pre-service science teachers were also concerned with the potential effects of gene therapy on humanity. Exploring college students' decision-making in genetically modified organisms (golden rice scenario), Lee and Lee (2015) revealed that students considered not only the benefits of gene technology but also considered side effects and problems associated with that specific technology. Indeed, in this study, pre-service teachers considered the benefits and positive effects of gene therapy on human health while indicating their concerns about the side effects of gene technologies. However, contrary to our finding, Simonneaux and Chouchane (2011) indicated that most of the participants favored gene therapies without a proper understanding of the uncertainties and risks associated with gene therapy. Contradicting findings of participants' risk perceptions about gene therapy might be explained in several ways. First, the complex and dynamic nature of genes makes it hard to understand the benefits and risk factors associated with gene technologies (Lederman et al. 2014). That is while an intervention to genes can create a disease-free society by deleting/changing an affected gene, it could also empower parents to design their own children by selecting desirable traits as Lederman et al. (2014) highlighted. Thus, weighting risk factors while making decisions in SSI is considered a requirement (Rattcliffe \& Grace, 2003). The second possible explanation is cultural differences in studies. Even all the participants in the aforementioned studies are university students (Lee \& Lee, 2015; Simonneaux \& Chouchane, 2011), the studies were conducted in different countries 
which can be a major source for cultural difference. Still, understanding participants' risk perceptions give us important clues about SSI teaching. It enables us to understand teachers' issue selection during SSI teaching (Hancock et al., 2019).

While gene technologies such as gene therapy are supported as they provide parents to have healthier off-springs, they are also criticized due to the complex and dynamic structure of genes, and the possibility of creating a 'genetic caste system' (Lederman et al., 2014). Thus, it is important to understand that gene technologies like gene therapy are not only beneficial but also consider risk factors due to the complex nature of genes and the possibility of empowering parents to design their own child by selecting desirable traits (Lederman et al., 2014). Actually, risk perception is assumed to be one of the underrepresented topics in science education research according to Christensen (2009). Kolstø (2006) revealed that all students used risk information as a central factor in their decision-making in SSI. As a result, including risk perception becomes crucial in SSI-based instruction.

Lastly, this study revealed that pre-service science teachers' opinions about the advancement of technology were focused on positive aspects, negative aspects, and considering the pros and cons of technological innovations. Similarly, Lee and Lee (2015) revealed that college students believed that while technology provides a solution to the problems, the technological tradeoffs (the loss and the benefits associated with the technology) are always evident. Wu and Tsai (2007) also revealed that students use science/technology-oriented arguments while decision-making in SSI. Lee and Lee (2015) argued that there is a contextual linkage between SSI and technology. SSI itself is a complex problem that is caused by not only pure scientific knowledge but also technology. As a result, the nature of technology can be included in SSI-based instruction and used for analyzing students' reasoning as well as promoting sophisticated decision-making in SSI (Lee \& Lee, 2015).

\section{CONCLUSION, LIMITATIONS, AND FUTURE DIRECTIONS}

This study revealed the context-dependent nature of SSI used in decision-making. While enhancing scientific literacy is referred to in many national and international policy documents, one way to achieve this is to develop informed decision-making skills in SSI. Thus, this study showed how future science teachers made decisions in an SSI topic, gene therapy, how they justified their decisions by using single or multiple informal reasoning patterns, and how their risk perceptions associated with the gene therapy and technology shaped their decisions.

This study has several limitations which can show directions for further studies: First, only female preservice science teachers participated in this study voluntarily. Thus, the results revealed in this study included only female teachers' perceptions about gene therapy. To be more inclusive, male pre-service science teachers can be included in interviews to get broader perspectives about gene therapy issues. Second, this study only included gene therapy as a context to investigate pre-service science teachers' informal reasoning and risk perceptions in gene therapy. Future studies should be conducted to reveal if the pre-service science teachers use similar informal reasoning patterns in different SSI topics (e.g., organ transplantation, global warming, or nuclear power plantation). This will help the researchers to understand whether there are common reasoning patterns used in different SSI topics. Another way is to develop pre-service science teachers' decision-making skills in SSI by adopting an intervention study specifically designed for this purpose. One last way might be including courses specifically focusing on SSI-based instruction to undergraduate teacher education programs which will prepare future teachers as efficient teachers who can implement SSI-based instruction in their future classes. While preparing future teachers for effective SSI-based instruction, there is also a strong need for in-service teachers who are already teaching in real classes. Short- or long-term professional development programs aiming to empower science teachers in implementing SSI-based instruction could be adopted for this purpose.

Author contributions: All authors were involved in concept, design, collection of data, interpretation, writing, and critically revising the article. All authors approve final version of the article.

Funding: The authors received no financial support for the research and/or authorship of this article. 
Declaration of interest: Authors declare no competing interest.

Data availability: Data generated or analysed during this study are available from the authors on request.

\section{REFERENCES}

Archibald, M. M. (2016). Investigator triangulation: A collaborative strategy with the potential for mixed methods research. Journal of Mixed Methods Research, 10(3), 228-250. https://doi.org/10.1177/1558689815570092

Bossér, U., Lundin, M., Lindahl, M., \& Linder, C. (2015). Challenges faced by teachers implementing socio-scientific issues as core elements in their classroom practices. European Journal of Science and Mathematics Education, 3(2), 159-176. https://doi.org/10.30935/scimath/9429

Braun, V., \& Clarke, V. (2012). Thematic analysis. In H. Cooper, P. M. Camic, D. L. Long, A. T. Panter, D. Rindskopf, \& K. J. Sher (Eds.), APA handbook of research methods in psychology, Vol. 2: Research designs: Quantitative, qualitative, neuropsychological, and biological (pp. 57-71). American Psychological Association.

Bryce, T., \& Gray, D. (2004). Tough acts to follow: the challenges to science teachers presented by biotechnological progress. International Journal of Science Education, 26(6), 717-733. https://doi.org/10.1080/0950069032000138833

Caelli, K., Ray, L., \& Mill, J. (2003). ‘Clear as mud': Toward greater clarity in generic qualitative research. International Journal of Qualitative Methods, 2(2), 1-13. https://doi.org/10.1177/160940690300200201

Carson, K., \& Dawson, V. M. (2016). A teacher professional development model for teaching socioscientific issues. Teaching Science, 62(1), 28-35.

Cebesoy, U. B. (2014). An analysis of science teachers' genetics literacy and related decision making process [Doctoral dissertation]. Middle East Technical University.

Chang Rundgren, S. N., \& Rundgren, C. J. (2010). SEE-SEP: From a separate to a holistic view of socioscientific issues. Asia-Pacific Forum on Science Learning \& Teaching, 11(1), 1-24.

Chen, L., \& Xiao, S. (2021). Perceptions, challenges and coping strategies of science teachers in teaching socioscientific issues: A systematic review. Educational Research Review, 100377. https://doi.org/10.1016/j.edurev.2020.100377

Christensen, C. (2009). Risk and school science education, Studies in Science Education, 45(2), 205-223. https://doi.org/10.1080/03057260903142293

Colucci-Gray, L., Camino, E., Barbiero, G., \& Gray, D. (2006). From scientific literacy to sustainability literacy: An ecological framework for education. Science Education, 90(2), 227-252. https://doi.org/10.1002/sce.20109

Cotton, D. R. E. (2006). Teaching controversial environmental issues: Neutrality and balance in the reality of the classroom. Educational Research, 48, 223-241. https://doi.org/10.1080/00131880600732306

Črne-Hladnik, H., Hladnik, A., Javornik, B., Košmelj, K., \& Peklaj, C. (2012). Is judgement of biotechnological ethical aspects related to high school students' knowledge?. International Journal of Science Education, 34(8), 1277-1296. https://doi.org/10.1080/09500693.2011.572264

Dawson, V., \& Carson, K. (2020). Introducing argumentation about climate change socioscientific issues in a disadvantaged school. Research in Science Education, 50(3), 863-883. https://doi.org/10.1007/s11165-018-9715-x

Dillon, J. (2009). On scientific literacy and curriculum reform. International Journal of Environmental and Science Education, 4(3), 201213.

Eggert, S., Ostermeyer, F., Hasselhorn, M., \& Bögeholz, S. (2013). Socioscientific decision making in the science classroom: The effect of embedded metacognitive instructions on students' learning outcomes. Education Research International, 1-12. http://dx.doi.org/10.1155/2013/309894

Es, H. \& Yenilmez Turkoglu, A. (2021). Using Q methodology to explore science teachers' socioscientific decision-making. International Journal of Research in Education and Science (IJRES), 7(3), 659-680. https://doi.org/10.46328/ijres.1479

Es, H., \& Varol, V. (2019). Fen bilgisi öğretmenliği ve ilahiyat öğrencilerinin nükleer santral sosyo-bilimsel konusuyla ilgili informal argümanları [in Turkish]. Mersin University Journal of the Faculty of Education, 15(2). 437-454. https://doi.org/10.17860/mersinefd.533013

Evren Yapicioglu, A., \& Aycan, S. (2018). Pre-service science teachers' decisions and types of informal reasoning about the socioscientific issue of nuclear power plants. Educational Policy Analysis and Strategic Research, 13(1), 31-53. https://doi.org/10.29329/epasr.2018.137.2

Fang, S. C., Hsu, Y. S., \& Lin, S. S. (2019). Conceptualizing socioscientific decision making from a review of research in science education. International Journal of Science and Mathematics Education, 17(3), 427-448. https://doi.org/10.1007/s10763-0189890-2

Fereday, J., \& Muir-Cochrane, E. (2006). Demonstrating rigor using thematic analysis: A hybrid approach of inductive and deductive coding and theme development. International Journal of Qualitative Methods, 5(1), 80-92. https://doi.org/10.1177/160940690600500107

Fowler, S. R., \& Zeidler, D. L. (2016). Lack of evolution acceptance inhibits students' negotiation of biology-based socioscientific issues. Journal of Biological Education, 50(4), 407-424. https://doi.org/10.1080/00219266.2016.1150869 
Gardner, G. E., \& Jones, M. G. (2011). Science instructors' perceptions of the risks of biotechnology: Implications for science education. Research in Science Education, 41(5), 711-738. https://doi.org/10.1007/s11165-010-9187-0

Gardner, G., Jones, G., Taylor, A., Forrester, J., \& Robertson, L. (2010). Students' risk perceptions of nanotechnology applications: implications for science education. International Journal of Science Education, 32(14), 1951-1969. https://doi.org/10.1080/09500690903331035

Genel, A., \& Topcu, M. S. (2016). Turkish preservice science teachers' socioscientific issues-based teaching practices in middle school science classrooms. Research in Science \& Technological Education, 34(1), 105-123. https://doi.org/10.1080/02635143.2015.1124847

Georgiou, M., Mavrikaki, E., Halkia, K., \& Papassideri, I. (2020). Investigating the impact of the duration of engagement in socioscientific issues in developing Greek students' argumentation and informal reasoning skills. American Journal of Educational Research, 8(1), 16-23. https://doi.org/10.12691/education-8-1-3

Gresch, H., Hasselhorn, M., \& Bögeholz, S. (2017). Enhancing decision-making in STSE education by inducing reflection and selfregulated learning. Research in Science Education, 47(1), 95-118. https://doi.org/10.1007/s11165-015-9491-9

Guion, R. M. (2002). Validity and reliability. In S. G. Rogelberg (Ed.), Handbook of Research Methods in Industrial-Organizational Psychology (pp. 57-76). Blackwell. https://doi.org/10.1002/9780470756669.ch3

Hancock, T. S., Friedrichsen, P. J., Kinslow, A. T., \& Sadler, T. D. (2019). Selecting socio-scientific issues for teaching: A grounded theory study of how science teachers collaboratively design SSI-based curricula. Science E Education, 28, 639-667. https://doi.org/10.1007/s11191-019-00065-x

Herman, B. C. (2018). Students' environmental NOS views, compassion, intent, and action: Impact of place-based socioscientific issues instruction. Journal of Research in Science Teaching, 55(4), 600-638. https://doi.org/10.1002/tea.21433

Herman, B. C., Feldman, A., \& Vernaza-Hernandez, V. (2017). Florida and Puerto Rico secondary science teachers' knowledge and teaching of climate change science. International Journal of Science and Mathematics Education, 15(3), 451-471. https://doi.org/10.1007/s10763-015-9706-6

Herman, B. C., Sadler, T. D., Zeidler, D. L., \& Newton, M. H. (2018). A socioscientific issues approach to environmental education. In International perspectives on the theory and practice of environmental education: A reader (pp. 145-161). Springer, Cham. https://doi.org/10.1007/978-3-319-67732-3_11

Higher Education Council [HEC]. (2007). Ogretmen Yetistirme ve Egitim Fakulteleri (1982-2007) [Teacher training and faculties of education (1982-2007)]. Higher $\quad$ Education Council. https://www.yok.gov.tr/Documents/Yayinlar/Yayinlarimiz/ogretmen-yetistirme-ve-egitim-fakulteleri.pdf

Hofstein, A., Eilks, I., \& Bybee, R. (2011). Societal issues and their importance for contemporary science education-a pedagogical justification and the state-of-the-art in Israel, Germany, and the USA. International Journal of Science and Mathematics Education, 9(6), 1459-1483. https://doi.org/10.1007/s10763-010-9273-9

Jho, H., Yoon, H. G., \& Kim, M. (2014). The relationship of science knowledge, attitude and decision making on socio-scientific issues: The case study of students' debates on a nuclear power plant in Korea. Science \& Education, 23(5), 1131-1151. https://doi.org/10.1007/s11191-013-9652-z

Kahn, S., \& Zeidler, D. L. (2017). A case for the use of conceptual analysis in science education research. Journal of Research in Science Teaching, 54(4), 538-551. https://doi.org/10.1002/tea.21376

Kara, Y. (2012). Pre-service biology teachers' perceptions on the instruction of socio-scientific issues in the curriculum, European Journal of Teacher Education, 35(1), 111-129. https://doi.org/10.1080/02619768.2011.633999

Karisan, D., \& Cebesoy, U. B. (2021). Use of the SEE-SEP model in pre-service science teacher education: The case of genetics dilemmas. In W. A. Powell (Ed.), Socioscientific Issues-Based Instruction for Scientific Literacy Development (pp. 223-254). IGI Global. https://doi.org/10.4018/978-1-7998-4558-4.ch008

Kirby, C. K. (2021). Determinants of undergraduates' environmental behavioural intentions and their links to socioscientific issues education. Interdisciplinary Journal of Environmental and Science Education, 17(2), e2231. https://doi.org/10.21601/ijese/9335

Kolstø, S. D. (2006). Patterns in students' argumentation confronted with a risk-focused socio-scientific issue. International Journal of Science Education, 28(14), 1689-1716. https://doi.org/10.1080/09500690600560878

Kolstø, S. D., Bungum, B., Arnesen, E., Isnes, A., Kristensen, T., Mathiassen, K., ... \& Ulvik, M. (2006). Science students' critical examination of scientific information related to socioscientific issues. Science Education, 90(4), 632-655. https://doi.org/10.1002/sce.20133

Lederman, N. G., Antink, A., \& Bartos, S. (2014). Nature of science, scientific inquiry, and socio-scientific issues arising from genetics: A pathway to developing a scientifically literate citizenry. Science \& Education, 23(2), $285-302$. https://doi.org/10.1007/s11191-012-9503-3

Lee, H., \& Lee, H. (2015). Analysis of students' socioscientific decision-making from the nature of technology perspectives. Journal of The Korean Association for Science Education, 35(1), 169-177. https://doi.org/10.14697/jkase.2015.35.1.0169

Lee, H., \& Witz, K. G. (2009). Science teachers' inspiration for teaching socio-scientific issues: Disconnectio n with reform efforts. International Journal of Science Education, 31(7), 931-960. https://doi.org/10.1080/09500690801898903

Lee, H., \& Yang, J. E. (2019). Science teachers taking their first steps toward teaching socioscientific issues through collaborative action research. Research in Science Education, 49(1), 51-71. https://doi.org/10.1007/s11165-017-9614-6 
Lee, H., Chang, H., Choi, K., Kim, S. W., \& Zeidler, D. L. (2012). Developing character and values for global citizens: Analysis of pre-service science teachers' moral reasoning on socioscientific issues. International Journal of Science Education, 34(6), 925953. https://doi.org/10.1080/09500693.2011.625505

Lee, Y. C. (2007). Developing decision-making skills for socio-scientific issues. Journal of Biological Education, 41(4), 170-177. https://doi.org/10.1080/00219266.2007.9656093

Levinson, R., Kent, P., Pratt, D., Kapadia, R., \& Yogui, C. (2012). Risk-based decision making in a scientific issue: A study of teachers discussing a dilemma through a microworld. Science Education, 96(2), 212-233. https://doi.org/10.1002/sce.21003

Liu, S. Y., Lin, C. S., \& Tsai, C. C. (2011). College students' scientific epistemological views and thinking patterns in socioscientific decision making. Science Education, 95(3), 497-517. https://doi.org/10.1002/sce.20422

Liu, S., \& Roehrig, G. (2019). Exploring science teachers' argumentation and personal epistemology about global climate change. Research in Science Education, 49 (1), 173-189. https://doi.org/10.1007/s11165-017-9617-3

Lombard, M., Snyder-Duch, J., \& Bracken, C. C. (2002). Content analysis in mass communication: Assessment and reporting of intercoder reliability. Human Communication Research, 28, 587-604. https://doi.org/10.1111/j.1468-2958.2002.tb00826.x

Merriam, S. B. (1998). Qualitative research and case study applications in education. Revised and expanded from case study research in education. Jossey-Bass.

Miles, M. B., \& Huberman, A. M. (1994). Qualitative data analysis: An expanded sourcebook. (2nd ed.). Sage Publications.

Ministry of National Education (MoNE). (2018). Primary science and technology curriculum for 3th-8th grades. http://mufredat.meb.gov.tr/ProgramDetay.aspx?PID=325

National Academies of Sciences, Engineering, and Medicine. (2016). Science literacy: Concepts, contexts, and consequences. The National Academies Press

National Research Council (1996). National Science Education Standards. National Academy Press.

Noy, C. (2008). Sampling knowledge: The hermeneutics of snowball sampling in qualitative research. International Journal of Social Research Methodology, 11(4), 327-344. https://doi.org/10.1080/13645570701401305

OECD. (2012). Assessment and analytical framework [E-reader version]. https://www.oecd.org/pisa/pisa-for-development/PISA-DAssessment-and-Analytical-Framework-Ebook.pdf

Oulton, C., Dillon, J., \& Grace, M. (2004). Reconceptualizing the teaching of controversial issues. International Journal of Science Education, 26(4), 411-423. https://doi.org/10.1080/0950069032000072746

Owens, D. C., Herman, B. C., Oertli, R. T., Lannin, A. A., \& Sadler, T. D. (2019). Secondary science and mathematics teachers' environmental issues engagement through socioscientific reasoning. Eurasia Journal of Mathematics, Science and Technology Education, 15(6), em1693. https://doi.org/10.29333/ejmste/103561

Owens, D. C., Sadler, T. D., \& Friedrichsen, P. (2019). Teaching practices for enactment of socio-scientific issues instruction: An instrumental case study of an experienced biology teacher. Research in Science Education, 51, 375-398. https://doi.org/10.1007/s11165-018-9799-3

Ozden, M. (2020). Elementary school students' informal reasoning and its' quality regarding socio-scientific issues. Eurasian Journal of Educational Research, 86, 61-84. https://doi.org/10.14689/ejer.2020.86.4

Patton, M. Q. (1990). Qualitative evaluation and research methods. (2nd ed.). Sage Publications.

Pedretti, E. (1999). Decision making and STS education: Exploring scientific knowledge and social responsibility in schools and science centers through an issues-based approach. School Science and Mathematics, 99, 174-181. https://doi.org/10.1111/j.1949-8594.1999.tb17471.x

Percy, W. H., Kostere, K., \& Kostere, S. (2015). Generic qualitative research in psychology. The Qualitative Report, $20(2), 76-85$. https://doi.org/10.46743/2160-3715/2015.2097

Pope, T., Dawson, V., \& Koul, R. (2017). Effect of religious belief on informal reasoning about biotechnology issues. Teaching Science, 63(2), 27-34.

Ratcliffe, M., \& Grace, M. (2003). Science education for citizenship: Teaching socio-scientific issues. McGraw-Hill Education.

Sadler, T. D., \& Donnelly, L. A. (2006). Socioscientific argumentation: The effects of content knowledge and morality. International Journal of Science Education, 28(12), 1463-1488. https://doi.org/10.1080/09500690600708717

Sadler, T. D., \& Zeidler, D. L. (2004a). The morality of socioscientific issues: Construal and resolution of genetic engineering dilemmas. Science Education, 88(1), 4-27. https://doi.org/10.1002/sce.10101

Sadler, T. D., \& Zeidler, D. L. (2004b). Negotiating gene therapy controversies. The American Biology Teacher, 66(6), 428-433. https://doi.org/10.2307/4451709

Sadler, T. D., \& Zeidler, D. L. (2005). Patterns of informal reasoning in the context of socioscientific decision making. Journal of Research in Science Teaching, 42(1), 112-138. https://doi.org/10.1002/tea.20042

Sadler, T. D., Amirshokoohi, A., Kazempour, M., \& Allspaw, K. M. (2006). Socioscience and ethics in science classrooms: Teacher perspectives and strategies. Journal of Research in Science Teaching, 43(4), 353-376. https://doi.org/10.1002/tea.20142

Sadler, T.D. (2004). Informal reasoning regarding socioscientific issues: A critical review of the literature. Journal of Research in Science Teaching 41(5), 513-536. https://doi.org/10.1002/tea.20009 
Simonneaux, L., \& Chouchane, H. (2011). The reasoned arguments of a group of future biotechnology technicians on a controversial socio-scientific issue: Human gene therapy. Journal of Biological Education, 45(3), 150-157. https://doi.org/10.1080/00219266.2011.582878

Tidemand, S., \& Nielsen, J. A. (2017). The role of socioscientific issues in biology teaching: From the perspective of teachers. International Journal of Science Education, 39(1), 44-61. https://doi.org/10.1080/09500693.2016.1264644

Topcu, M. S., Yılmaz-Tüzün, Ö., \& Sadler, T. D. (2011). Turkish preservice science teachers' informal reasoning regarding socioscientific issues and the factors influencing their informal reasoning. Journal of Science Teacher Education, 22(4), 313332. https://doi.org/10.1080/09500690903524779

van der Zande, P., Waarlo, A. J., Brekelmans, M., Akkerman, S. F., \& Vermunt, J. D. (2011). A knowledge base for teaching biology situated in the context of genetic testing. International Journal of Science Education, 33(15), 2037-2067. https://doi.org/10.1080/09500693.2010.525797

Wu, Y. T., \& Tsai, C. C. (2007). High school students' informal reasoning on a socio-scientific issue: Qualitative and quantitative analyses. International Journal of Science Education, 29(9), 1163-1187. https://doi.org/10.1080/09500690601083375

Wu, Y. T., \& Tsai, C. C. (2011). High school students' informal reasoning regarding a socioscientific issue, with relation to scientific epistemological beliefs and cognitive structures. International Journal of Science Education, 33(3), 371-400. https://doi.org/10.1080/09500690903505661

Zangori, L., Foulk, J., Sadler, T. D., \& Peel, A. (2018). Exploring elementary teachers' perceptions and characterizations of modeloriented issue-based teaching. Journal of Science Teacher Education, 29(7), 555-577. https://doi.org/10.1080/1046560X.2018.1482173

Zeidler, D. L., Walker, K. A., Ackett, W. A., \& Simmons, M. L. (2002). Tangled up in views: Beliefs in the nature of science and responses to socioscientific dilemmas. Science Education, 86, 343-367. https://doi.org/10.1002ce.10025

Zohar, A. \& Nemet, F. (2002). Fostering students' knowledge and argumentation skills through dilemmas in human genetics. Journal of Research in Science Teaching, 39, 35-62. https://doi.org/10.1002/tea.10008 
APPENDIX A- Scenarios (Adapted from Sadler and Zeidler, 2005)

\section{Scenario 1: Huntington's Disease Gene Therapy}

Huntington's disease (HD) is a neurological disorder caused by a single gene. Its symptoms usually start between the ages of 35 and 45 . The first symptoms include uncontrollable body spasms and cognitive impairment. As the disease progresses, patients become physically incapacitated, suffer from emotional instability, and eventually lose mental faculties. HD usually runs its course over 15-20 years and always results in death. No conventional treatments are known to work against HD.

Because Huntington's disease is controlled by one gene, it could be a candidate for gene therapy. Should gene therapy be used to eliminate HD from sex cells (egg cells or sperm cells) that will be used to create new human offspring?

\section{Scenario 2: Intelligence Gene Therapy}

We know that a person's intelligence is controlled by a variety of factors including both environmental and genetic influences. Several genes likely contribute to a person's intelligence. No single factor, whether genetic or environmental, could completely determine an individual's intelligence; however, it is conceivable that scientists could find a single gene that at least contributed to an individual's intelligence.

If science were able to isolate a gene that significantly contributed to a person's intelligence, should that gene be used for gene therapy to increase the intelligence of potential offspring? 


\section{APPENDIX B- Sample Questions (Adapted from Sadler and Zeidler, 2005)}

1. What factors were influential in determining your position regarding the Huntington's disease issue?

2. Did you consider the responsibility of parents? If so, what are the responsibilities of the parents in this scenario?

3. Did you consider the rights of the future child? If so, how did this affect your decision-making?

4. Did you consider whether or not a parent has the right to alter the child's genes? If so, how did this affect your decision-making?

5. Do you think that gene therapy as described in this case is subject to any kind of moral rules or principles? If so, how did this affect your decision-making?

The questions were modified according to scenarios (Huntington's disease and intelligence) 